\title{
The First Chimurenga: 1896-1897 Uprising in Matabeleland and Mashonaland and Continued Conflicts in Academia
}

\author{
Suzanne Dawson
}

\begin{abstract}
In this article, it will be argued that the First Chimurenga, or uprising in Southern Rhodesia was a complex set of struggles over land, cattle, and taxes rather than a planned, unified movement intended to overthrow the whites; neither the Africans nor the British were unified. It will evaluate historiography available on the subject, analyzing various weaknesses in scholarship due to the inherent lack of primary source material available from indigenous perspectives.
\end{abstract}

In order to explore largely ignored aspects of African resistance to colonialism which was important in shaping later twentieth century African liberation movements, this article focuses upon African societies, not the British settlers, nor Cecil Rhodes who was not in Southern Rhodesia at the time of the revolts. The First Chimurenga was a compelling demonstration of early African resistance movements. However, the historiography for the First Chimurenga is incomplete, and in this paper I aim to discuss and analyze flaws and gaps in this historiography. In some cases this paper reflects those gaps and contradictions, as some elements of Shona and Ndebele religious practices and culture remain unknown. Scholars' perceptions provide a valuable source for analysis as they can reveal enduring problems in conceptualizations of the First Chimurenga. Studies of this event are often riddled with holes due to the challenging nature of primary sources which are lacking in primary accounts from Indigenous peoples themselves.

In this article, I argue that the First Chimurenga, or uprising, which took place from 1896-1897 in Southern Rhodesia, now Zimbabwe, was a complex set of struggles over land, cattle, and taxes. Rather than a planned, cohesive movement intended to overthrow the whites, neither the Africans nor the British were unified. The British South Africa Company (B.S.A.C)'s failure to understand the Shona and Ndebele peoples' local grievances and reasons to rise up complicates perceptions of the event. An investigation of the roles played by spirit mediums and the Mwari cult in the uprisings, (focussing on Nehanda in particular) also adds dimension. Moreover, I will examine debates surrounding leadership of the movement. For example, Mapondera's role as a leader of African resistance through social banditry in addition to the historic meaning of the legacy left by the symbolic figures of Nehanda and Mapondera provide an interesting study into the uprising. A discussion of the questions raised by the First Chimurenga and why these questions remain unresolved will conclude the article. I will present the contradictory viewpoints regarding the causes of the First Chimurenga and analyze ways in which these viewpoints are flawed.

Prior to contact with Europeans, African societies were complex, with their own political, economic, and social systems. These societies were not 'backwards,' 'static,' or 'primitive.' Rather; they were complicated and dynamic, with institutions worth defending. This was demonstrated in the reaction of the Shona and Ndebele societies in Southern Rhodesia, now Zimbabwe, when the British began resource extraction and settlement colonies in the late nineteenth century. The Ndebele and Shona societies were primarily agrarian, and dispersed. Both the Ndebele and Shona relied heavily upon cattle and land as primary commodities. Cattle in particular were important in linking communities and families together through trade and lobola, or bride wealth. When white settlers arrived in

Constellations

Volume 2, No. 2 (Winter 2011) 
greater numbers, and began stealing land and cattle, and imposing a hut tax to force members of these societies to sell their labour, the Ndebele and Shona revolted. However, these African societies were not simply unified against the whites. These African societies were in reality complex and often internally divided, with some members of society cooperating with the whites and benefiting from white settlers through trade while other members of society were oppressed. The idea of African nationalism has been attributed to early resistance movements, which I argue is anachronistic, and fails adequately account for local interests and internal divisions. I explore these divisions in this paper.

The First Chimurenga took place from 1896-1897, first in Matabeleland and then in Mashonaland. The reasons for this uprising are a point of debate, as well as how this uprising was carried out by the Shona and Ndebele people. The primary point of debate begins with Terence Ranger's portrayal of the First Chimurenga as a "supra-tribal" uprising led and organized by the spirit mediums and political leaders, which were the beginnings of a "national consciousness." Later arguments presented by historians such as Julian Cobbing and David Beach hold that the First Chimurenga was actually a series of fragmented uprisings that were not rooted in nationalism. Ranger's argument is flawed in that he attributes nationalism and an anti-colonial struggle to uprisings which were more likely fragmented and based upon local grievances. However Cobbing and Beach are unable to further explain this fragmentation effectively, and commit the same errors in source interpretation as Ranger. Historians of the First Chimurenga do not have access to many primary Shona and Ndebele accounts of the uprisings, and have thus interpreted the uprisings primarily through the eyes of the British who participated in ending the First Chimurenga.

In the B.S.A.C publication "The '96 Rebellions," Earl Grey, the Administrator of Rhodesia cites two principle causes of the rebellion in Matabeleland: First, the incompleteness of the conquest of the Matabele Nation in 1893 and second, the incapacity of a warlike and aristocratic race to give up their old habits and to accept their natural place in the peaceful and industrial organization of a settled civilized community. ${ }^{1}$

These causes demonstrate the complete lack of understanding that Grey and B.S.A.C administration had for Ndebele social, political, and economic structures. The Ndebele were labelled "warlike," over-emphasizing Ndebele links to the Zulu. Although these links existed, they were not a primary force in the rebellion. The British were stunned by the uprisings, viewing them as irrational and due to Ndebele unwillingness to take their natural place as conquered peoples. The British had tried to avoid 'harassing' the local population; however the 'natives' still desired to rid the land of the white settlers. ${ }^{2}$ The British saw the chances of such violent uprisings were remote, and, consequently, were taken by surprise when they did occur. The revolt was attributed to the M'Limo and the concurrent events of rinderpest, drought, and the arrival of white settlers. The M'Limo was viewed as a Matabele superstition by the British. Thus the revolts were perceptively a hysterical reaction rooted in superstitions against environmental disaster caused by the whites' arrival. This perception was favoured over viewing the uprising as a reasoned response to oppressive social measures such as taxes, loss of land, and loss of cattle. ${ }^{3}$ The uprising in Mashonaland began later than the Matabeleland uprising, however the Shona people shared many of the same grievances as the Ndebele people. The Shona and Ndebele peoples had previously been in conflict when the Ndebele

\footnotetext{
${ }^{1}$ British South Africa Company Reports on the Native Disturbances in Rhodesia, 1896-97. The '96 Rebellions, Rhodesian Reprint Library Silver Series Volume Two, Books of Rhodesia Bulawayo. (1975): 5.

2 B.S.A.C., 5.

${ }^{3}$ B.S.A.C, 6 .
}

Constellations

Volume 2, No. 2 (Winter 2011) 
invaded Shona territory; the groups did not share common interests at the time the B.S.A.C arrived; therefore the First Chimurenga was not likely a unifying event.

The First Chimurenga is difficult to explain from a western perspective because societal structures differ so dramatically. There are gaps in the historiography of the First Chimurenga as a result. Those involved were not interviewed in depth, and there were few first hand Shona and Ndebele accounts of the revolts. British records are the primary written source of these revolts, and these accounts are flawed. British accounts fail to account for cultural nuances. Although spirit mediums played an important role during the First Chimurenga, the nature of that role is a point of confusion. Spirit mediums provided a form of cohesion, legitimate power, and spiritual authority. However, the confusion over their roles arises because spirit mediums did not exert their power directly when influencing secular politics. Feierman discusses how historians fundamentally disagree over whether or not spirit mediums who led the war existed at all. ${ }^{4}$ Feierman addresses the fundamental issue of how invisible histories are ignored when African culture is viewed through colonial perspectives. This debate is played out in arguments presented by Ranger and Beach. Ranger presents the argument that spirit mediums were key leaders in coordinating the First Chimurenga whereas Cobbing and Beach debate the extent of this leadership. These arguments are primarily drawn from British archives, which present an incomplete and biased view of the uprising; the British saw it as primitive superstition rather than a legitimate societal institution.

The assertion made by Ranger and Feierman that the spirit mediums did play a key role in the organization and structure of Ndebele and Shona society is relevant, however just how unifying a factor this was remains unknown. I argue that spirit mediums did play a key role in the First Chimurenga, as Ranger argues in Revolt in Southern Rhodesia 1896-1897. In the uprisings in both Mashonaland and Matabeleland, Ranger posits that they were organized with spirit mediums playing key role by providing unified leadership. Ranger argues that in Matabeleland and Mashonaland, the Mwari cult was a centralizing force though there was no single cult center in 1896. There were four major cult centers with equal power which provided areas of influence over different groups on the region. ${ }^{5}$ The Mwari cult required consultation and discussion among different leaders in order to take action, creating an intelligence network. According to Ranger, the evidence suggests in the early months of 1896 that Ndebele leaders (particularly Umlugulu and Mpotshawana) were in contact with these leading priestly families, thereby increasing their own legitimacy. This is in part due to circumstances created by the drought, locusts, and rinderpest problems that were a severe threat to fertility. Africans viewed these problems as a result of whites not making peace with the land or accommodating Mwari; everyone involved was being divinely punished. ${ }^{6}$ At this level, it was a cultural and religious misunderstanding. Africans believed that by removing the whites from the land that the environmental problems would end. As a result, the leading officers of the Mwari cult provided moral support and organization to the preparations for the rebellion; the risings broke out in three areas where shrines were influential. ${ }^{7}$ Ranger effectively argues that Africans had powerful institutions in place that provided purpose and direction to the revolts.

\footnotetext{
${ }^{4}$ Steven Feierman. "Colonizers, Scholars and the Creation of Invisible Histories," from V.E. Bonnell, L. Hunt (eds), Beyond the Cultural Turn, University of California Press, 1999, 188.

5 Terence Ranger. Revolt in Southern Rhodesia 1896-97 A Study in African Resistance. Evanston: Northwestern University

Press, 1967, 145-146.

${ }^{6}$ Ibid., 147-148.

7 Ibid., 148.
} 
In addition to their ritual role, spirit mediums played a political role in the Mutapa kingdom. They legitimized the power of the king and limited his power; the most powerful spirit mediums were those of Mutota, Chingoo, Dzivaguru, Chaminuka and Nehanda. According to Ranger, the control these mediums held over large amounts of territory was the closest thing to a national focus that the Shona had. ${ }^{8}$ Spirit mediums were important in both Shona and Ndebele culture because they stabilized secular society in addition to legitimizing it through ritual. I agree with Ranger that the spirit mediums did play an important role in the First Chimurenga because they served such an integral role within Shona and Ndebele society. However, that role was only partially responsible for the uprisings. Ranger argues that the senior medium Nehanda played a key role in unification although the importance of the medium of Nehanda had been downplayed in official circles. ${ }^{9}$ Ranger cites Selous as one of the misleading sources. Some historians have interpreted Selous otherwise, leading to disagreement over spirit mediums (particulary the Nehanda medium). Based on an interview with an elderly man living on the Chiweshe Resrve, Ranger argues that Nehanda's influence was dominant in the Mazoe area, and was behind the rebellion from the start. According to this man, Nehanda is responsible for the rain and sometimes fighting. Nehanda helped bring Mashonaland into the rising through coordinating with other mediums. The spirit mediums served as a way to link society; this remains only a part of why the revolt occurred in 1896-1897.

The role of spirit mediums and African religious cults in general is a point of debate due to cultural differences, source limitations, and source interpretations. Cobbing presents an effective critique of Ranger's book in his article "The Absent Priesthood: Another Look at the Rhodesian Risings of 1896-1897." However, Cobbing's article is also flawed in that it fails to consider the key role of the Mwari cult and spirit mediums in Shona and Ndebele societies. Cobbing effectively challenges Ranger's anachronistic attribution of nationalism to the First Chimurenga and ways in which Ranger's account of the Mwari cult does not differ significantly from the B.S.A.C report on supernatural forces and witch doctors. Cobbing effectively identifies ways in which Ranger's Africanist sympathies have influenced his book, but credits Ranger for his work on African grievances such as forced labour, cattle seizures, and the hut tax. ${ }^{10}$ Cobbing raises a key question: "is it necessary to postulate this 'coordinating factor,' or to rummage for a 'secret history' of the wars when in most respects the nature of the risings and the manner in which Africans fought reflected very closely the structures of participating political units?"11 This question of the coordinating factor is a key critique of Ranger, however Cobbing's argument misses the wider African cultural context.

The exact role of spirit mediums in the First Chimurenga remains unknown, and it is difficult to determine this role by using British archival records and without more primary Shona and Ndebele sources. Cobbing's own conclusions about the role of the spirit mediums are flawed. Cobbing rightly identifies problematic ways in which Ranger's analysis relies too heavily upon British hysteria over 'Mlimos' and 'witchdoctors' inciting irrational violence upon the settler population. This focus misses the important role of the Mwari cult in Ndebele and Shona society. ${ }^{12}$ Cobbing's argument-that the history of the Mwari cult's dominance in the First Chimurengis the history of a myth-misses important ways in which spirit mediums played a role in leadership and political legitimacy. Cobbing accurately describes the complexity and fragmentation of the movements as an important

\footnotetext{
${ }^{8}$ Ibid., 20.

9 Ibid., 209.

10 Julian Cobbing. "The Absent Priesthood: Another Look at the Rhodesian Risings of 1896-1897," The Journal of African History, Vol. 18, No. 1 (1977): 62.

11 Cobbing. 63.

12 Cobbing, 81.
} 
reason for failure to remove the British. He simultaneously is unable to analyze the deeper role spirit mediums played in Ndebele and Shona culture. ${ }^{13}$ Though the Mwari cult was not pervasive and coordinated, it should not be dismissed as a minor part of Shona and Ndebele society. Further exploration on the nature of the Mwari cult and the role of the spirit mediums is needed.

Another strong critique of the role of spirit mediums in the First Chimurenga has been made by David Beach. Beach re-examines the role of Shona spirit mediums in the uprising in his article "An Innocent Woman, Unjustly Accused? Charwe, Medium of the Nehanda Mhondoro Spirit, and the 1896-97 Central Shona Rising in Zimbabwe." Beach raises important questions regarding the significance of mediums in leading the uprisings. However, he misses the cultural meaning of spirit mediums by choosing to focus upon the figure of the woman possessed by the spirit of Nehanda rather than what the spirit possession actually meant to Shona society. ${ }^{14} \mathrm{By}$ dismissing the significance of this possession because it is safest, Beach places a Shona religious figure into a incongruous western context, thus failing to explore how Nehanda influenced, led, and legitimized Shona society. Focussing solely on Charwe the woman misses key elements of Shona culture. Beach examines resistance in this article, and does acknowledge the significance of Nehanda in the movement. Yet he fails to consider the belief system as a major factor in Nehanda's role. While Nehanda has become a popular symbol of resistance to colonial rule in modern Zimbabwe, that does not mean historical interpretations of her contribution can be dismissed solely as legendary. ${ }^{15}$ Beach relies too heavily upon what he considers established 'facts' drawn from British records, and as a result does not explore Nehanda in the context of Shona beliefs.

The role of Nehanda is difficult to determine as a result of widely held western beliefs about the legitimacy of African belief systems such as the Mwari cult and the role it played in Shona society. This is made more difficult by the lack of written African records regarding the role of Nehanda. Instead, historians have drawn primarily from incomplete British archival records. Beach explains the historical Nehanda as a legend, describing how she was the daughter of the founding ancestor of the Mutapa dynasty who lived in the fifteenth century and became a mbondoro spirit after her death. ${ }^{16}$ However describing the history of Nehanda as a legend misses the significance of the ritual role the Nehanda spirit medium played in Shona society. This ritual significance is of key importance in Shona history. Although some aspects of Nehanda's role in the uprising have likely been exaggerated, this does not diminish the ritual significance of Nehanda within the cultural belief system. Beach does not deny that the Nehanda spirit medium was a major factor in the war but he neglects her important role. By ignoring aspects of history which cannot be empirically proven, Beach obscures that Nehanda played a key role in the war ..

Beach makes a valid argument that Ranger had not challenged the role of Nehanda anymore than the colonial writers. Simultaneously, by focussing on critiques of this aspect of Ranger's argument, he does not further the actual role played by the Nehanda medium in Shona culture. Beach commits the same error as Ranger and Cobbing by relying on British archival reports. They do not consider that British reports lacked in information because they were from an entirely different culture's perspective. For example, Beach uses trial evidence to demonstrate through 'facts' that Charwe, claiming possession by Nehanda, was integral to the uprising. He states "there is no direct evidence

\footnotetext{
13 Cobbing, 78.

14 David Beach. "An Innocent Woman, Unjustly Accused? Charwe, Medium of the Nehanda Mhondoro Spirit, and the 1896-97 Central Shona Rising in Zimbabwe,” History in Africa, Vol. 25 (1998): 29.

15 Beach, 27.

16 Beach, 27.
} 
from the 1898 trials that Charwe played any special part in the beginning of the rising, whereas the same sources make it quite clear that Gumboreshumba, the medium of the Kaguvi spirit, was influential in the Chivero-Nyamweda, Zvimba, and eastern Salisbury districts."17 Beach's presentation of evidence is compelling, however, by relying on such trial evidence, he misses elements of Shona culture which were unknown to the British and were therefore unrecorded or misinterpreted as "witchcraft." Contradictions in Charwe's evidence may lie in cultural misunderstandings from a British trial of a Shona medium, rather than 'factual' contradictions. Beach accurately identifies problems with the way that hysteria, rumour, and Rhodesian preconceptions regarding Shona religion have distorted history. Yet he does not adequately address those misperceptions in a manner, choosing to simply dismiss them as rumour. ${ }^{18}$ Beach's own cultural expectations heavily influence his interpretation of historical documents. This issue is also a factor in how the historical figure of Mapondera has been portrayed.

The First Chimurenga has been defined as a historical turning point in African resistance in which Ndebele and Shona groups united to rid Matabeleland and Mashonaland of the British invaders. However the reality was more complex than what has been portrayed in historical writings. African resistance did exist and Africans did have a way of life and social system to protect. However they were often fragmented, and were not engaged in an anti-colonial movement as it has recently been defined. However, sections of the population did come together against common threats such as conscripted labour, loss of land, and loss of cattle. The role of leadership is debated in this resistance; a key historical figure that has come to symbolize African resistance is the figure of Mapondera. Mapondera has been portrayed as a leader of early peasant protest by Allen Isaacman, a historically distorted and controversial figure by David Beach, and as a "soldier of Zimbabwe" in the novel by Solomon M. Mutswairo. Each of these portrayals is significant in that they demonstrate the complexity of interpreting the roles played by historical figures. Mapondera was a complex and controversial figure who has come to symbolize early African resistance, linked by some to modern Zimbabwe. This link is nonetheless problematic in that it misses the complexity of Mapondera in favour of nationalist aims.

One portrayal of Mapondera is that of a social bandit who led small anti-colonial resistance movements against the British at the time of the First Chimurenga. In "Social Banditry in Zimbabwe (Rhodesia) and Mozambique, 1894-1907: An Expression of Early Peasant Protest," Allen Isaacman presents the compelling argument that Mapondera was a primary leader in social protest movements against the British. In 1890 the British South Africa Company moved into Shona territory along with European settlers and a police force. Though this British group was weak at the time, the Native Affairs Department was organized in 1894 and began collecting taxes in 1895. This development, according to Isaacman, was the beginning of a process of peasantization in which the self-sustaining Shona agriculturalists were transformed into peasants who producing in and subordinate to an economic system regulated by the colonial state, though the European presence was actually quite weak at the time. In order to overcome a labour shortage, the British South Africa Company sought to force Africans into the labour market by imposing the 1895 hut tax which compelled Africans to sell their labour. Those who failed to pay the hut tax suffered confiscation of cattle, loss of land, and imprisonment. ${ }^{19}$ This imposition was a direct attack upon Shona institutions. Land chiefs who protested against these demands were arrested, and spirit mediums, who served as guardians of the

\footnotetext{
17 Beach, 34.

18 Beach, 39.

19 Allen Isaacman, "Social Banditry in Zimbabwe (Rhodesia) and Mozambique, 1894-1907: An Expression of Early

Peasant Protest," Journal of Southern African Studies, Vol. 4, No. 1, (1977): 7.
} 
natural social order, were also arrested. ${ }^{20}$ It was in this context that Mapondera operated as part of greater African resistance movements, particularly in Mozambique, headed by Dambukashamba. ${ }^{21}$ However the extent of these resistance movements is controversial; the life of Mapondera remains a key point of this controversy.

Mapondera's ancestry has been traced back to the Rozvi royal family of Changamire, thus giving him the legitimacy to defend Rozvi leadership and threats to Shona society as a whole. ${ }^{22}$ Mapondera has been credited with carrying out military exploits surpassing his father, Gorenjena, who was said to be invulnerable in battle; he famously removed a spear from his own body and used it to kill his opponent. ${ }^{23}$ This heritage made Mapondera out to be an ideal warrior to defend Shona institutions and society. Prior to fighting against British incursions, Mapondera was said to have triumphed over the Ndebele leader Chikwarmakomo during the Ndebele raids upon the Shona in which the Ndebele destroyed much of the Shona land and population in the Mazoe region. ${ }^{24}$ This portrayal of Mapondera as a soldier was then extended to battles against the British. Mapondera worked with the first European traders until the presence of Europeans became a threat; once this took place, his role shifted to that of a social bandit defending his people. Isaacman cites two specific incidents which led to this shift and both of these incidents are said to have directly impacted Mapondera's family. One of these incidents involved a trader shooting Mapondera's brother Ruwanga in the hand; villages who witnessed the incident attacked the trader and Ruwanga was subsequently arrested for the incident. ${ }^{25}$ This incident and the overall oppression drove Mapondera to become a social bandit, leaving Nyota and forming a community of others who had been oppressed by colonialism; his links extended into Mozambique. This group of peasant outlaws attacked colonial symbols of oppression: they raided government posts, ambushed tax collectors, attacked labour recruiters, and burned rural shops which were exploiting the peasants. ${ }^{26}$ The high point of Mapondera's role as a social bandit was 1900; however the resistance movement was too fragmented and weak to have a lasting impact upon the British who were increasing in force and numbers. ${ }^{27}$ Mapondera and the idea of social banditry are important points of debate, and are directly linked to the context in which the First Chimurenga was carried out.

Mapondera remains a key figure in Shona history because he embodies the rich history of the Rozvi Changamire dynasty, the importance of African culture, and ways in which Africans resisted colonialism. Mapondera is the subject of the novel Mapondera: Soldier of Zimbabwe, by Solomon M. Mutswairo. This novel is not a historical work, however it is important in history because it demonstrates how Mapondera has come to symbolize African resistance in general and Shona culture specifically. This novel is historically problematic in that it glorifies the life of Mapondera; it is the story of an epic hero. However it is historically significant in that some of the details do not differ dramatically from some historical accounts of Mapondera's life, demonstrating how much remains unknown about Mapondera and has thus been interpreted to fit a national narrative or Africanist history. This novel places Mapondera at the forefront of the resistance movement, as the

\footnotetext{
20 Isaacman, 8.

${ }^{21}$ Isaacman, 13.

22 Isaacman, 9.

23 Isaacman, 10.

24 Isaacman, 10.

${ }^{25}$ Isaacman, 11.

${ }^{26}$ Isaacman, 14.

${ }^{27}$ Isaacman, 16.
} 
symbol of Rozvi independence. ${ }^{28}$ Mapondera is credited with the aim of fighting to restore the ancient glory of Rozvi by battling against the expansionism and exploitation of Cecil Rhodes and the British South Africa Company. ${ }^{29}$ While Mapondera was more complex than what was written in this novel, Mutswairo does provide insights into African beliefs and rituals, as well as how Mapondera came to be a symbol of Shona resistance.

The portrayal of Mapondera by Isaacman, Ranger, and Mutswairo is contested by David Beach in his article "From Heroism to History: Mapondera and the Northern Zimbabwean Plateau, 18401904." Beach wrote this article after Isaacman, and thus had access to more archival records. Beach effectively lays out alternatives and complexities within the life of Mapondera, such as the problems in tracing his genealogy and ways in which Mapondera was not simply fighting to maintain the glory of the Rozvi Empire. Beach effectively calls into question the extent to which Mapondera fought against colonialism by providing information regarding ways in which Mapondera worked with the Europeans at times and was not fighting for an ideal or social justice. Beach accurately identifies the flaws in previous historical works. However, he claims to present evidence in an empirical manner, supposedly allowing reader to assess the uprising from the 'facts.' Importantly, his 'facts' neglect to place events in their proper context, thus detracting from the power of his argument and leaving historical details unexplained. For example, Beach argues that "it is a crucial part of my argument that Mapondera's actions can be understood only in terms of his own perceptions." 30 This statement is misleading, because it is impossible for any historian to determine what Mapondera's own perceptions actually were. However Beach does present a valid argument regarding Mapondera's role in African resistance by exploring historical discrepancies. For example, how prominent Mapondera actually was within Shona society is a point of debate; according to Beach's source, Mapondera was not recognized as supreme by the houses of Nyota, let alone Negomo. Thus Mapondera was not actually an independent ruler and did not have the authority to make concessions in Negomo's territory. Mapondera may have declared himself independent but this was

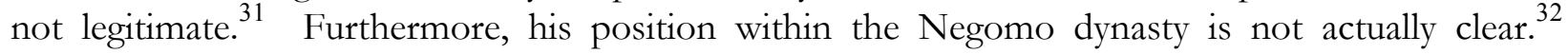
Another key point that Beach discusses is what Mapondera's motives actually were. Mapondera likely had mixed motives for his actions, rather than fighting solely for the glory of the Rozvi state or social justice. For example, the incident involving Rwanga may have had more complications than what Isaacman presented. Mapondera's reasons for leaving Nyota included the hut tax collection and the arrest of his brother Rwanga. However, Beach presents another aspect of this event; Mapondera and Rwanga were said to have been on very bad terms due to unpaid brideprice for Mapondera's mother, thus it would have made more sense for Mapondera to stay and receive the cattle Rwanga owed him. Secondly, records that Mapondera resisted tax collection are incomplete and disputed. It is possible that not much livestock was lost in tax collection by July 1895, and that Mapondera was disputing the collection of taxes by people other than himself. ${ }^{33}$ This calls into question what role Mapondera did have in resistance, and how that role was likely far more complicated than has been discussed historically.

\footnotetext{
${ }^{28}$ Solomon M. Mutswairo, Mapondera, Soldier of Zimbabwe, Three Continents Press Inc. Washington D.C. (1978):

${ }^{29}$ Mutswairo, 21.

${ }^{30}$ David Beach, "From Heroism to History: Mapondera and the Northern Zimbabwean Plateau, 1840-1904," History in Africa, Vol. 15, (1988): 85.

31 Beach, 100.

32 Beach, 104.

33 Beach, 105.
}

Constellations

Volume 2, No. 2 (Winter 2011) 
In conclusion, figures such as Mapondera and fragmented acts of social banditry serve to demonstrate the social and political context in which the First Chimurenga took place. The spirit mediums were integral to Ndebele and Shona societal institutions, however, society overall was too fragmented for them to have led a supra-tribal uprising against the British. The spirit mediums likely legitimized small scale battles but overall the movements were not coordinated on a large scale. The First Chimurenga was not a unified, anti-colonialist movement against the British South Africa Company and white settlers; however the First Chimurenga did arise out of a set of grievances. This complex set of struggles was rooted in smaller uprisings such as social banditry movements, and can be considered African resistance. The Shona and Ndebele were fighting to defend their way of life, social institutions, and culture; however the movement as a whole was fragmented. Evaluating scholars' perspectives reveal that the First Chimurenga continues to be a source of contention. Oftentimes historians' own perceptions influence their historical analyses, thus complicating the already muddied waters of scanty and problematic primary sources which serve as records for the uprising. Many questions remain in regards to the role of spirit mediums, the figure of Mapondera, and the nature of the First Chimurenga. 


\section{Bibliography}

Beach, David. The Shona and Their Neighbours. Oxford: Blackwell Publishers, 1994.

--. "From Heroism to History: Mapondera and the Northern Zimbabwe Plateau 1840-1904," History in Africa, Vol. 15, (1988), 85-161.

--. "Ndebele Raiders and Shona Power," The Journal of African History, Vol. 15, No. 4. (1974), 633-651.

--. "Chimurenga: The Shona Rising of 1896-97," The Journal of African History, Vol. 20, No. 3. (1979): 395-420.

--. "An Innocent Woman, Unjustly Accused? Charwe, Medium of the Nehanda Mhondoro Spirit, and the 1896-97 Central Shona Rising in Zimbabwe," History in Africa, Vol. 25 (1998): 27-54.

The British South Africa Company Reports on the Native Disturbances in Rhodesia, 1896-97. "The '96 Rebellions," in Rhodesiana Reprint Library - Silver Series Volume Two, Books of Rhodesia Bulawayo 1975.

Cobbing, Julian. “The Evolution of Ndebele Amabutho," The Journal of African History, Vol. 15, No. 4. (1974), 607-631.

--. "The Absent Priesthood: Another Look at the Rhodesian Risings of 1896-1897," The Journal of African History, Vol. 18, No. 1. (1977): 61-84.

Feierman, Steven. "Colonizers, Scholars and the Creation of Invisible Histories", from V.E. Bonnell, L. Hunt (eds), Beyond the Cultural Turn, University of California Press, 1999, pp. 182-216. (2009 Coursepack)

Isaacman, Allen. "Social Banditry in Zimbabwe (Rhodesia) and Mozambique, 1894-1907: An Expression of Early Peasant Protest," Journal of Southern African Studies, Vol. 4 No. 1 (1977): 1-30.

Laurie, Charles. Every Man Has His Price. Lanham: University Press of America, 2008.

Martin, David., and Johnson Phyllis. The Struggle for Zimbabwe: The Chimurenga War. London: Faber and Faber Limited, 1981.

Mason, Philip. The Birth of a Dilemma: The Conquest and Settlement of Rhodesia. London: Oxford University Press, 1958.

Mutswairo, Solomon M. Mapondera Soldier of Zimbabwe. Washington: Three Continents Press Inc., 1978.

Ranger, Terence. Revolt in Southern Rhodesia 1896-97 A Study in African Resistance. Evanston: Northwestern University Press, 1967. 